$607 \cdot 4$

\title{
perforadora de suelos
}

La EBCO Ltd. ha construido un último modelo que añadir a su gama de perforadoras.

Se trata del modelo núm. 3, manejado por dos hombres, capaz de efectuar un taladro de $30 \mathrm{~cm}$ de diámetro hasta una profundidad de 9 metros.

En condiciones ideales es capaz de realizar un pozo de $3 \mathrm{~m}$ de profundidad y $12 \mathrm{~cm}$ de diámetro en 15 minutos.

Una característica distintiva de este modelo es el tipo de caja de cambios de sinfín y corona, consistente en un tornillo sinfín de acero especial que engrana con una corona de bronce fosforoso. Este tipo de caja de cambios es la primera vez que se usa en esta clase de maquinaria.

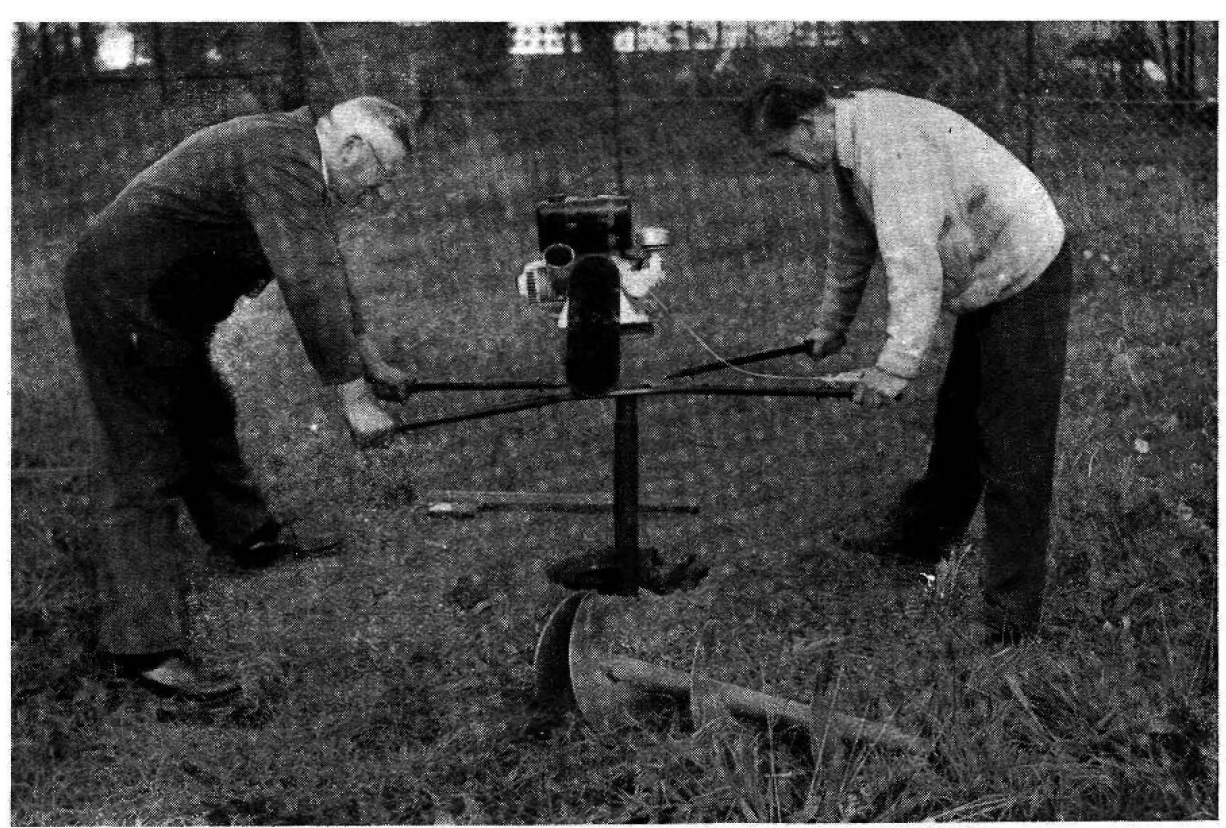

El motor es de dos tiempos, refrigerado por aire, alimentado y lubricado por una mezcla de fuel $\dot{y}$ aceite, pueden ser acoplados tres tipos distintos desde $41 / 2$ a 8 H.P. de acuerdo con las necesidades.

La transmisión está dotada de un embrague centrífugo, que desembraga la caja de cambios para velocidades lentas del motor, produciéndose el embrague automáticamente al accionar el acelerador, el cual está situado en uno de los brazos de sujeción como se ve en la fotografía.

Este modelo de perforadora puede instalarse en un montaje apropiado, que permite efectuar perforaciones horizontales para la colocación de cables, tubos, etc., a través de carreteras sin perturbar el tráfico.

Esta perforadora está construida por la Earth Boring Machine Co. Lake Works, Portchester, Hants (Inglaterra), de la que no existe representación en España.

M. CHINCHILLA 